\title{
Effectiveness of oil displacement by sequential low-salinity waterflooding in low-permeability fractured and non-fractured chalky limestone cores
}

\author{
Abdulrazag Y. Zekri ${ }^{1}$ B Benny A. Harahap ${ }^{1} \cdot$ Hazim H. Al-Attar ${ }^{1}$ · Essa G. Lwisa ${ }^{1}$
}

Received: 18 February 2018 / Accepted: 10 May 2018 / Published online: 31 May 2018

(c) The Author(s) 2018

\begin{abstract}
Low-salinity waterflooding has been recognized as a method of enhancing oil recovery in low-permeability reservoirs. This method is relatively inexpensive and can be easily implemented in the field. Various mechanisms of low-salinity flooding have been proposed including interfacial tension reduction, wettability alteration (cation exchange), change in $\mathrm{pH}$ (increase), emulsion formation, and clay migration. Hydraulic fracturing has been known as a technique of stimulating hydrocarbon flow from low-permeability matrix into wellbores by creating high-conductivity fractures. The objective of this study is to evaluate the effectiveness of sequential low-salinity brine flooding process to enhance oil recovery in low-permeability fractured and non-fractured chalky limestone core samples. The low-salinity waterflooding tests were conducted with synthetic brines of five different salinity concentrations, namely, 157,662, 72,927, 62,522, 6252, and $1250 \mathrm{ppm}$. The properties of these brines have been thoroughly investigated in the laboratory. The crude oil and chalky limestone core samples, permeability range between 0.01 and 1.2 millidarcy, were gathered from a selected oil field in United Arab Emirates. When used as an opening move in a three-stage sequential brine flooding $\left(\mathrm{SW} / 10 \rightarrow \mathrm{SW} / 50 \rightarrow \mathrm{SW} 6 \mathrm{XSO}^{-2}\right)$, sea water diluted ten times at $6252 \mathrm{ppm}$ (SW/10) has been found to yield the highest oil recovery in fractured and non-fractured tests at the prevailing reservoir conditions, of 82.64 and $76 \%$ of OOIP, respectively. In all sequential brine flooding scenarios tested, sea water with sulfate concentration spiked six times ( $\mathrm{SW} 6 \times \mathrm{SO}_{4}{ }^{-2}$ ) only slightly increased oil recovery. The highest observed incremental recovery with sulfate spiking was $2.083 \%$ of OOIP. The effectiveness of oil displacement by sequential brine flooding has been attributed to mineral dissolution and fines migration which resulted in a favorable wettability alteration. This postulation of flow mechanism is confirmed by introducing a "flow resistance index" concept and measurements of key properties of the injected and effluent brines of each stage of the attempted sequential brine flooding scenarios. Results of this study could be consulted when selecting most efficient EOR method to develop tight carbonate oil reservoirs in the UAE and worldwide.
\end{abstract}

Keywords Enhanced oil recovery $\cdot$ Low-permeability $\cdot$ Carbonate reservoir $\cdot$ Low-salinity waterflooding $\cdot$ Hydraulic fracturing

\section{Background}

The world energy demand is not static and it is forecasted to increase rapidly. Although the world is rapidly moving in the direction of using a mix of energy, it is expected that $53 \%$ of the world's energy needs will be met by oil and gas in 2040 (Ban et.al. 2016). Therefore, we can safely say

Hazim H. Al-Attar

hazim.alattar@uaeu.ac.ae

1 Chemical and Petroleum Engineering Department, UAE University, P.O. Box 15551, Al Ain, UAE that oil will be a major player for the energy market for the next 30 years at least. Carbonate reservoirs contribute more than $60 \%$ of the world's petroleum production. Carbonate reservoirs (limestone or dolomite) are heterogeneous and require major skills to understand and develop a detailed reservoir description. Low-permeability carbonate reservoirs have been considered uneconomical to develop because of their low flow rates and longer pay out times. Oil in lowpermeability oil reservoirs is classified as unconventional reserves. Unconventional reserve is defined by the oil industry as 'hard to recover' oil. The definition 'hard to recover' reserve includes reservoirs having low-permeability and/or porosity. The oil recovery by waterflooding technology is not 
known as an effective method in low-permeability carbonate oil reservoirs. To maximize the wellbore-reservoir contact area in these low-permeability reservoirs, a number of oil companies completed horizontal wells with multiple hydraulic fracturing stages. In spite of above-mentioned technological advances, low-permeability oil reservoirs exhibit a huge variety of geological characteristics that makes the application of a single technique (completion/development) unrealistic and might lead to unfavorable economical and/ or technical conditions. Therefore, an innovative exploration/exploitation strategy is required for optimal hydrocarbon recovery from low-permeability oil reservoirs. Consequently, research has been directed to develop new methods to improve oil recovery from this type of reservoirs.

In this work, we have investigated the possibility of using low-salinity, sequential low-salinity waterflooding, fracturing, and combination of sequential low-salinity flooding with hydraulic fracturing to improve oil recovery from lowpermeability carbonate reservoirs. The objective is to determine the optimum technique for a selected low-permeability carbonate oil reservoir.

A substantial amount of research work has been conducted on the possibility of using low-salinity waterflooding in recovering oil from conventional sandstone and carbonate oil reservoirs Al-Quraishi et al. (2015). AlHarrasi et al. (2012) investigated the performance of lowsalinity using carbonate rocks and reported a significant oil recovery up to $16 \%$ of original oil in place. Al-Attar et. al. (2013) investigated the effect of divalent ion concentration of the performance of low-salinity waterflooding and they concluded that sulfate concentration plays a major role on flood performance. Bagci et al. (2001) used dilutions of formation brine as injection system and they reported a success story in limestone rocks. Austad et al. (2010) indicated that fine migration is a major player in performance of low-salinity in carbonate oil reservoirs. Yi and Sarma (2012) reported that multi-ionic exchange concept is the mechanism in both sandstone and carbonate keeping in mind that the process in carbonate reservoirs is quite different from that in sandstone reservoirs. Zekri et al. (2011) reported that wettability alteration is the dominant mechanism in both sandstone and carbonate rocks. Alameri et al. (2015) reported that the low-salinity waterflood in low-permeability carbonate rocks yielded incremental oil recovery of up to $9 \%$. Alameri is the only author to our knowledge investigated the possibility of using low-salinity in low-permeability rocks. Comprehensive review on the mechanism of low-salinity flooding was conducted by Sheng (2014). He reported based on the literature review that several mechanism responsible for the success of low-salinity flooding. Although there are no clear consensus on the process mechanism, the majority attributed the improvement of oil recovery to wettability alteration. Other mechanism includes interfacial tension reduction, rock dissolution, ionic exchange, and oil emulsion also reported as possible mechanism. In most of the cases, it seems no single mechanism is responsible for the improvement of oil recovery by low-salinity flooding, but rather a combination of previously mentioned mechanism acting at different degrees.

\section{Experimental procedures and materials}

The experimental setup used in this work is designed to perform coreflooding tests by sequential brine injection with and without simulated induced single fracture. A flow chart demonstrating the sequence of the laboratory tests performed in this study is shown in Fig. 1. All flooding scenarios were conducted at simulated reservoir temperature and pressure. All materials including crude oil, core samples, and composition of injected water were provided by Abu Dhabi Company for Onshore Petroleum Operations Ltd. (ADCO).
Fig. 1 Flowchart illustrating the sequence of laboratory tests

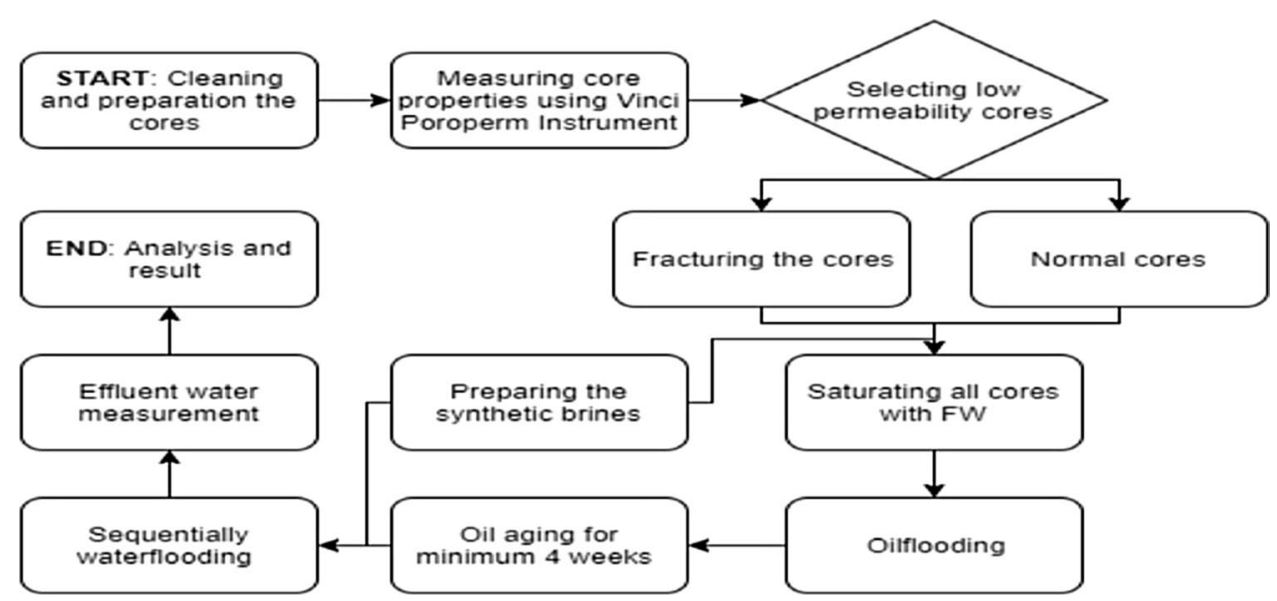




\section{Crude oil}

Sweet crude oil sample with API gravity of 39.48 degrees is collected from Asab Field. This field is one of the five major fields operated by ADCO. The viscosity of this crude oil is $2.927 \mathrm{cp}$ under ambient conditions and $1.8953 \mathrm{cp}$ under 255F and 3100 psia.

\section{Brines}

Five brines were used in this study including formation water of Asab Field (FW), seawater (SW), seawater diluted 10 times (SW/10), seawater diluted 50 times (SW/50), and seawater with sulfate concentration spiked 6 times (SW $6 \times \mathrm{SO}_{4}^{-2}$ ). The compositions of these five brines are listed in Table 1 and their densities and viscosities at ambient conditions are presented in Table 2 .

\section{Core samples}

Nine chalky limestone $\left(\mathrm{CaCO}_{3}\right)$ core samples from Zakum Oil Field were used in this work. The results of their routine core analysis are presented in Table 3.

\section{Simulating hydraulically induced fractures}

The induced fracture was synthetically created by cutting the core sample into equal halves along the entire length of the core and as illustrated in Fig. 2. Aluminum foil was then placed between the core two halves to keep the simulated fracture face open and the outer surface area of the core was wrapped up with aluminum foil to keep the core intact. Four core samples were prepared this way, namely ZK-454-6F, ZK-454-11F, ZK-454-20F, and ZK-454-27F. The results of liquid permeability measurements of these core samples before and after fracture simulation are presented in Table 4 .

\section{Oilflooding and aging process}

All core plugs were fully saturated with formation water and then flooded with oil to $S_{w i}$ then aged for 5 weeks. The results of this part of the experimental work are listed in Table 5.

\section{Sequential waterflooding tests}

These tests represent the major part of this study. It was intended to assess selected brines as potential fluids to enhance oil recovery under simulated reservoir conditions. Flooding tests were conducted sequentially starting with high salinity brines followed by lower salinities and sulfate

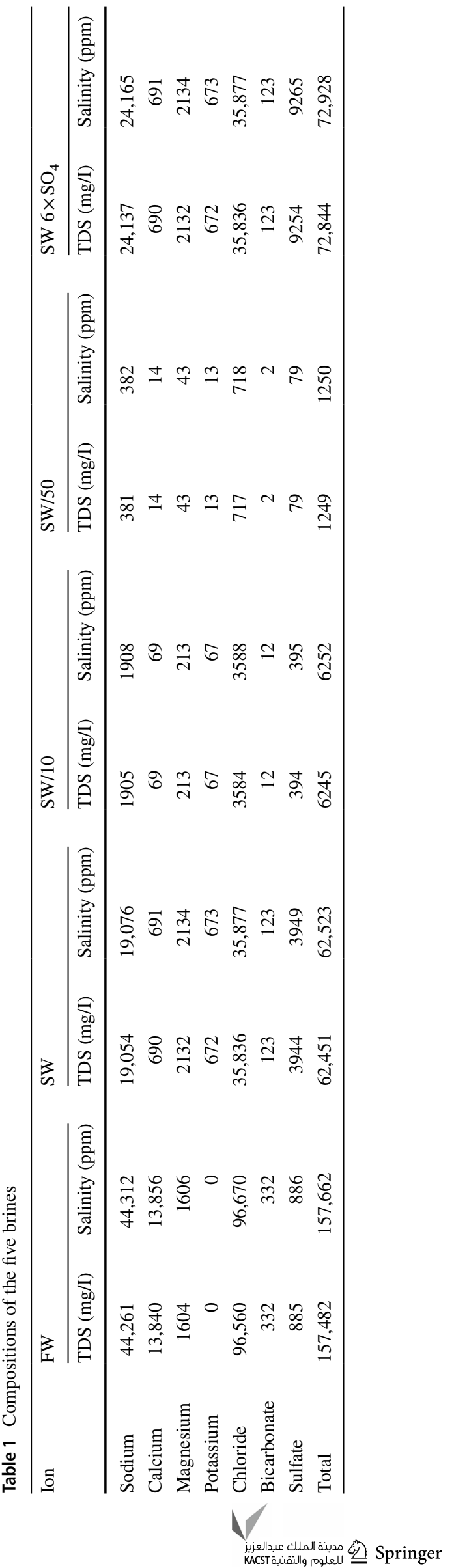


Table 2 Density and viscosity of the five brines

\begin{tabular}{llll}
\hline No. & Brine & Density $(\mathrm{g} / \mathrm{m} 1)$ & Viscosity $(\mathrm{cP})$ \\
\hline 1 & $\mathrm{FW}$ & 1.103 & 1.35 \\
2 & $\mathrm{SW}$ & 1.034 & 1.19 \\
3 & $\mathrm{SW} / 10$ & 1 & 1.07 \\
4 & $\mathrm{SW} / 50$ & 1 & 1.03 \\
5 & $\mathrm{SW} \mathrm{6} \times \mathrm{SO}_{4}{ }^{2-}$ & 1.05 & 1.26 \\
\hline
\end{tabular}

spiked using the coreflooding system setup as shown in Fig. 3. The sequential brine flooding scenarios of the nine core samples used in this work are presented in Table 6.

All the tests were conducted under similar reservoir conditions, an overburden pressure of $2500 \mathrm{psia}$ (applied using the hydraulic pump) and temperature of $90{ }^{\circ} \mathrm{C}$ (core holder is equipped with a heating jacket). The injection rate of brines was kept constant at $1 \mathrm{cc} / \mathrm{min}$ throughout each sequential flooding scenario. A back pressure regulator was installed to control the outlet pressure at 100 psi to regulate the flow and avoid extra pressure build-up after heating the system. During each sequential flooding scenario, the salinity, resistivity, $\mathrm{pH}$, and conductivity of the effluent water were measured. Salinity in ppm and resistivity in ohm.meter were measured using a digital resistivity meter. Conductivity $(\mathrm{mS} / \mathrm{cm})$ and $\mathrm{pH}$ values were measured using a digital conductivity meter and digital $\mathrm{pH}$ meter, respectively.
Table 4 Liquid permeability before and after fracturing

\begin{tabular}{|c|c|c|c|}
\hline \multirow[t]{2}{*}{ Core no } & \multicolumn{2}{|c|}{ Permeability liquid(mD) } & \multirow{2}{*}{$\begin{array}{l}\text { Folds of perme- } \\
\text { ability increase }\end{array}$} \\
\hline & Initial & Fractured & \\
\hline ZK-454-6F & 0.32 & 2.23 & 7.0 \\
\hline $\mathrm{ZK}-454-11 \mathrm{~F}$ & 0.02 & 6.97 & 348.3 \\
\hline ZK-454-20F & 0.02 & 3.02 & 150.8 \\
\hline ZK-454-27F & 1.7 & 3.88 & 2.3 \\
\hline
\end{tabular}

\section{Results and discussion}

During each stage of the attempted sequential waterflooding scenarios, the volumes of the produced and injected fluids as well as the pressure drop across the core were carefully and continuously measured as a function of time. Due to space limitation, the results of one sequential brine flooding scenario of the non-fractured core ZK-454-3 are presented in Table 7 and Fig. 4. A complete set of all the results of this work can be found in Benny (2017).

In addition to the above and for the same core sample, the end-point effective permeability to brine of each flooding stage within the above sequential flood scenario $\left(k_{\text {weff }}\right)$ was calculated using Darcy's equation at residual oil residual $\left(S_{o r}\right)$. The viscosity of various brines at $90{ }^{\circ} \mathrm{C}$ was estimated using an empirical correlation developed

Table 3 Results of routine core analysis of the nine samples

\begin{tabular}{lllllllllll}
\hline Sample id & Dry wt & $\begin{array}{l}\text { Length } \\
(\mathrm{gm})\end{array}$ & $\begin{array}{l}\text { Diameter } \\
(\mathrm{cm})\end{array}$ & $\begin{array}{l}\text { Pore vol. } \\
(\mathrm{cm})\end{array}$ & $\begin{array}{l}\text { Bulk vol. } \\
\text { air }(\mathrm{cc})\end{array}$ & $\begin{array}{l}\text { Grain vol. } \\
(\mathrm{cc})\end{array}$ & $\begin{array}{l}\text { Grain den. } \\
\text { air }(\mathrm{cc})\end{array}$ & $\begin{array}{l}\text { Porosity } \\
(\mathrm{gm} / \mathrm{cc})\end{array}$ & $\begin{array}{l}\text { Permeability } \\
\text { air }(\%)\end{array}$ & $\begin{array}{l}\text { Air }(\mathrm{md}) \\
\text { Liquid (md) }\end{array}$ \\
\hline ZK-454-2 & 171.93 & 6.818 & 3.801 & 13.45 & 77.4 & 63.94 & 2.69 & 17.4 & 0.15 & 0.09 \\
ZK-454-3 & 174.4 & 6.932 & 3.803 & 13.7 & 78.77 & 65.07 & 2.68 & 17.4 & 0.25 & 0.16 \\
ZK-454-4 & 175.95 & 7.103 & 3.794 & 14.48 & 80.33 & 65.85 & 2.67 & 18 & 0.24 & 0.15 \\
ZK-454-5 & 169.77 & 6.998 & 3.801 & 15.8 & 79.44 & 63.64 & 2.67 & 19.9 & 1.06 & 0.73 \\
ZK-454-6 & 135.81 & 5.418 & 3.812 & 10.86 & 61.86 & 51 & 2.66 & 17.5 & 0.49 & 0.32 \\
ZK-454-11 & 124.35 & 5.305 & 3.793 & 13.95 & 59.97 & 46.02 & 2.7 & 23.3 & 0.02 & 0.01 \\
ZK-454-13 & 141.22 & 6.234 & 3.801 & 18.43 & 70.77 & 52.33 & 2.7 & 26 & 0.98 & 0.66 \\
ZK-454-20 & 125.13 & 5.279 & 3.806 & 13.66 & 60.08 & 46.43 & 2.7 & 22.7 & 0.05 & 0.03 \\
ZK-454-27 & 131.59 & 5.684 & 3.8 & 15.7 & 64.49 & 48.79 & 2.7 & 24.3 & 1.7 & 1.2 \\
\hline
\end{tabular}

Fig. 2 Simulating a single induced fracture

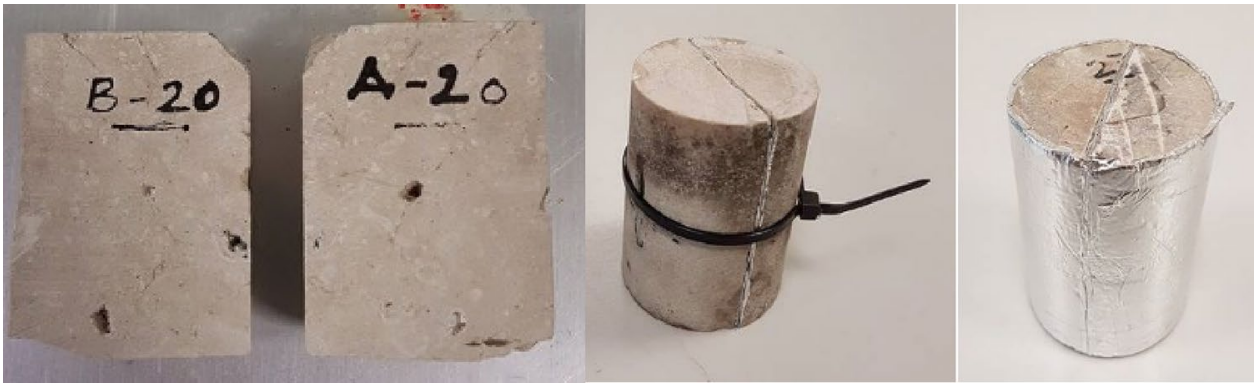


Table 5 Results of flooding core samples to $S_{w i}$

\begin{tabular}{|c|c|c|c|c|c|c|c|c|c|}
\hline No. & Core ID & Length $(\mathrm{cm})$ & Diameter $(\mathrm{cm})$ & $\begin{array}{l}\text { Pore Vol by } \\
\text { water }(\mathrm{cc})\end{array}$ & $\begin{array}{l}\text { Porosity by } \\
\text { water }(\%)\end{array}$ & $\begin{array}{l}\text { Permeability by } \\
\text { water (md) }\end{array}$ & $\begin{array}{l}\text { Produced } \\
\text { Water }(\mathrm{cc})\end{array}$ & Swi & Soi \\
\hline 1 & ZK-454-2 & 6.818 & 3.801 & 11.818 & 15.276 & 0.09 & 9.5 & 0.196 & 0.804 \\
\hline 2 & ZK-454-3 & 6.932 & 3.803 & 11.628 & 14.767 & 0.16 & 9.1 & 0.217 & 0.783 \\
\hline 3 & ZK-454-4 & 7.103 & 3.794 & 12.244 & 15.247 & 0.15 & 10 & 0.183 & 0.817 \\
\hline 4 & ZK-454-5 & 6.998 & 3.801 & 13.622 & 17.154 & 0.73 & 11.3 & 0.170 & 0.830 \\
\hline 5 & ZK-454-13 & 6.234 & 3.801 & 15.688 & 22.178 & 0.66 & 11.5 & 0.267 & 0.733 \\
\hline 6 & ZK-454-6F & 5.418 & 3.862 & 9.075 & 14.299 & 2.23 & 7 & 0.229 & 0.771 \\
\hline 7 & ZK-454-11F & 4.619 & 3.843 & 9.888 & 18.455 & 6.97 & 7.2 & 0.272 & 0.728 \\
\hline 8 & ZK-454-20F & 4.703 & 3.856 & 9.045 & 16.469 & 3.02 & 7.4 & 0.182 & 0.818 \\
\hline 9 & ZK-454-27F & 5.684 & 3.850 & 12.416 & 18.764 & 3.88 & 10 & 0.195 & 0.805 \\
\hline
\end{tabular}

Fig. 3 Schematic of coreflooding experimental set up; v1, v2, and $\mathrm{v} 3$ are isolation valves

Table 6 Sequential waterflooding scenarios

\section{A SKETCH FOR WATER AND OIL FLOODING SYSTEM AT RESERVOIR CONDITIONS}

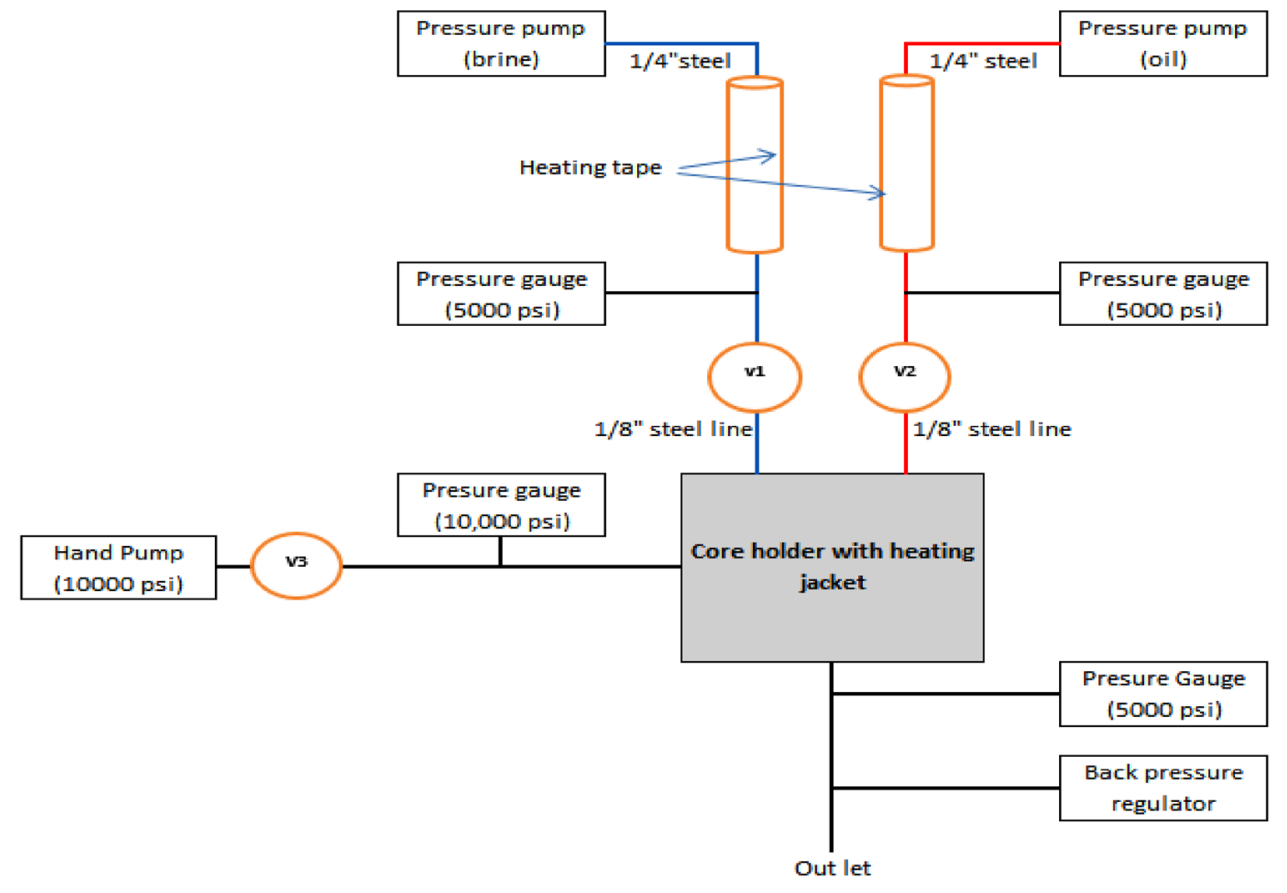

No. Sample id Order of brines injected

\begin{tabular}{lllllll}
\cline { 3 - 6 } & & 1st & 2nd & 3rd & 4th & 5th \\
\hline 1 & $\mathrm{Z} \mathrm{K}-454-2$ & $\mathrm{SW}$ & $\mathrm{SW} / 10$ & $\mathrm{SW} / 50$ & $\mathrm{SW} 6 \times \mathrm{SO}_{4}{ }^{2-}$ & \\
2 & $\mathrm{Z} \mathrm{K}-454-3$ & $\mathrm{FW}$ & $\mathrm{SW}$ & $\mathrm{SW} / 10$ & $\mathrm{SW} / 50$ & $\mathrm{SW} 6 \times \mathrm{SO}_{4}{ }^{2}$ \\
3 & $\mathrm{Z} \mathrm{K}-454-4$ & $\mathrm{SW} / 10$ & $\mathrm{SW} / 50$ & $\mathrm{SW} 6 \times \mathrm{SO}_{4}{ }^{2}$ & & \\
4 & $\mathrm{Z} \mathrm{K}-454-5$ & $\mathrm{SW} / 50$ & $\mathrm{SW} 6 \times \mathrm{SO}_{4}{ }^{2}$ & & & \\
5 & $\mathrm{Z} \mathrm{K}-454-13$ & $\mathrm{SW} 6 \times \mathrm{SO}_{4}{ }^{2}$ & $\mathrm{SW} / 50$ & & & \\
6 & $\mathrm{Z} \mathrm{K}-454-6 \mathrm{~F}$ & $\mathrm{FW}$ & $\mathrm{SW}$ & $\mathrm{SW} / 10$ & $\mathrm{SW} / 50$ & $\mathrm{SW} 6 \times \mathrm{SO}_{4}{ }^{2}$ \\
7 & $\mathrm{Z} \mathrm{K}-454-11 \mathrm{~F}$ & $\mathrm{SW} / 10$ & $\mathrm{SW} / 50$ & $\mathrm{SW} 6 \times \mathrm{SO}_{4}{ }^{2-}$ & & \\
8 & $\mathrm{Z} \mathrm{K}-454-20 \mathrm{~F}$ & $\mathrm{SW}$ & $\mathrm{SW} / 10$ & $\mathrm{SW} / 50$ & $\mathrm{SW} 6 \times \mathrm{SO}_{4}{ }^{2}$ & \\
9 & $\mathrm{Z} \mathrm{K}-454-27 \mathrm{~F}$ & $\mathrm{SW} 6 \times \mathrm{SO}_{4}{ }^{2-}$ & $\mathrm{SW} / 50$ & & & \\
\hline
\end{tabular}


Table 7 Results of sequential flooding scenario of a nonfractured core sample ZK-454-3

\begin{tabular}{|c|c|c|c|c|c|c|c|}
\hline No. & Injected Brines & $\begin{array}{l}\text { Voil pro- } \\
\text { duced (cc) }\end{array}$ & $\begin{array}{l}\text { Vwater } \\
\text { Injected } \\
\text { (cc) }\end{array}$ & $\begin{array}{l}\text { Incremental } \\
\operatorname{RF}(\%)\end{array}$ & RF (\%) & $\begin{array}{l}\text { Incremental } \\
\text { PV injected }\end{array}$ & PV injected \\
\hline \multirow[t]{7}{*}{1} & \multirow[t]{7}{*}{ FW } & 0 & 0 & 0.000 & 0.000 & 0.000 & 0.000 \\
\hline & & 3.9 & 6.1 & 42.857 & 42.857 & 0.860 & 0.860 \\
\hline & & 0.8 & 9.2 & 8.791 & 51.648 & 0.860 & 1.720 \\
\hline & & 0.4 & 9.6 & 4.396 & 56.044 & 0.860 & 2.580 \\
\hline & & 0.2 & 9.8 & 2.198 & 58.242 & 0.860 & 3.440 \\
\hline & & 0.1 & 9.9 & 1.099 & 59.341 & 0.860 & 4.300 \\
\hline & & 0 & 9.4 & 0.000 & 59.341 & 0.808 & 5.108 \\
\hline \multirow[t]{2}{*}{2} & \multirow[t]{2}{*}{ SW } & 0.6 & 17.3 & 6.593 & 65.934 & 1.542 & 6.651 \\
\hline & & 0 & 34.7 & 0.000 & 65.934 & 2.981 & 9.632 \\
\hline \multirow[t]{2}{*}{3} & \multirow[t]{2}{*}{ SW/10 } & 0.3 & 17.4 & 3.297 & 69.231 & 1.525 & 11.157 \\
\hline & & 0 & 34.9 & 0.000 & 69.231 & 2.999 & 14.156 \\
\hline \multirow[t]{2}{*}{4} & \multirow[t]{2}{*}{$\mathrm{SW} / 50$} & 0.2 & 17.4 & 2.198 & 71.429 & 1.511 & 15.667 \\
\hline & & 0 & 34.7 & 0.000 & 71.429 & 2.987 & 18.654 \\
\hline \multirow[t]{2}{*}{5} & \multirow[t]{2}{*}{$\mathrm{SW} 6 \times \mathrm{SO}_{4}^{2-}$} & 0.1 & 17.5 & 1.099 & 72.527 & 1.509 & 20.163 \\
\hline & & 0 & 34.9 & 0.000 & 72.527 & 3.001 & 23.164 \\
\hline
\end{tabular}

ZK-454-3

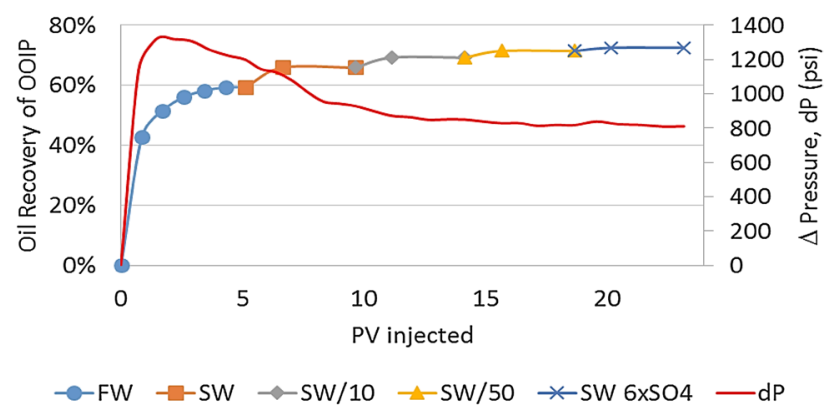

Fig. 4 Oil recovery as per cent of OOIP and pressure drop across versus PV injected for core sample ZK-454-3
Fig. 5 End-point effective permeability to brines of the sequential flood scenario of the non-fractured core sample ZK-454-3

\section{ZK-454-3}

by El-dessouky (2002). The results of end-point effective permeability calculations are shown in Fig. 5.

\section{Sequential low-salinity waterflooding of non-fractured cores}

A summary of the results of sequential coreflooding scenarios of non-fractured core samples is shown in Table 8 . By comparing the results of cores ZK-454-2 and ZK-4543 , it can be sated that less volume of injected brines is required to recover approximately the same amount of oil without the injection of FW. All sequential flooding scenarios were conducted at a constant injection rate of $1 \mathrm{cc} /$ min. The pressure drop at $S_{o r}$ was recorded for each stage of every sequential scenario as presented in Table 8. A general trend of declining pressure drop can be observed with decreasing brine salinity. Such a trend is indicative

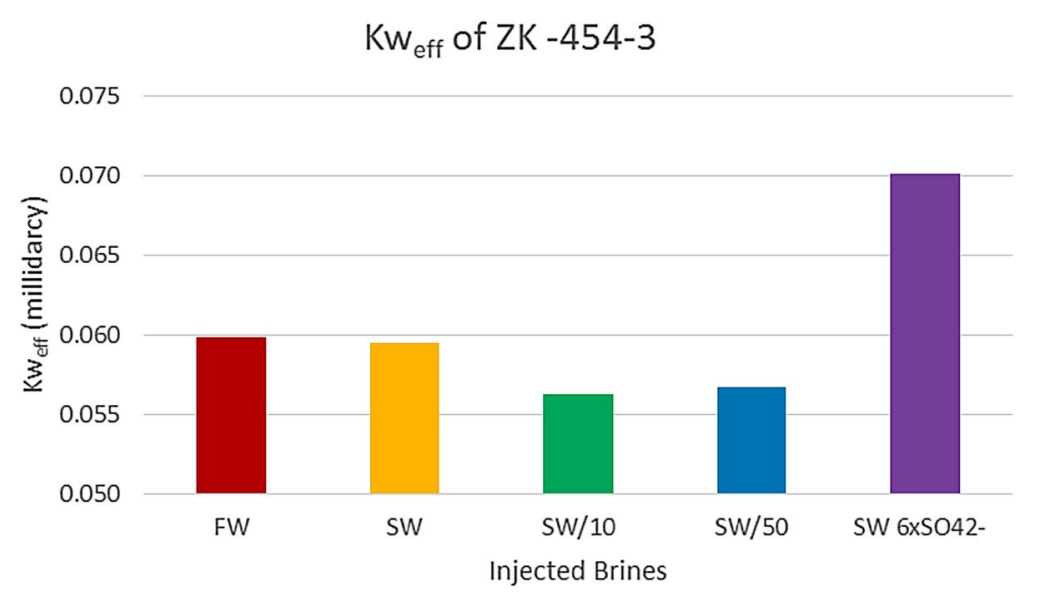


Table 8 Summary of results of sequential flooding scenarios of non-fractured core samples

\begin{tabular}{|c|c|c|c|c|c|c|c|c|c|c|}
\hline No. & Core ID & Injected Brines & $\begin{array}{l}\text { Voil } \\
\text { Produced } \\
\text { (cc) }\end{array}$ & $\begin{array}{l}\text { Vwater } \\
\text { Injected } \\
\text { (cc) }\end{array}$ & $\begin{array}{l}\text { Incremen- } \\
\text { tal RF } \\
(\%)\end{array}$ & $\mathrm{RF}$ & $\begin{array}{l}\text { Incremental } \\
\text { PV injected }\end{array}$ & PV injected & $\mathrm{AP}$ at $\mathrm{S}_{\mathrm{or}}(\mathrm{psi})$ & $\begin{array}{l}\mathrm{Kw}_{\text {eff }} \text { at Sor } \\
\text { estimated (mil- } \\
\text { lidarcy) }\end{array}$ \\
\hline \multirow[t]{4}{*}{1} & \multirow[t]{4}{*}{ ZK-454-2 } & SW & 6.1 & 59.1 & 64.211 & 64.211 & 5.001 & 5.001 & 1250 & 0.044 \\
\hline & & SW/10 & 0.3 & 52.6 & 3.158 & 67.368 & 4.451 & 9.452 & 1136 & 0.041 \\
\hline & & $\mathrm{SW} / 50$ & 0.25 & 52.35 & 2.632 & 70.000 & 4.430 & 13.881 & 1115 & 0.041 \\
\hline & & $\mathrm{SW} 6 \times \mathrm{SO}_{4}{ }^{2-}$ & 0.15 & 52.55 & 1.579 & 71.579 & 4.447 & 18.328 & 1120 & 0.050 \\
\hline \multirow[t]{5}{*}{2} & \multirow[t]{5}{*}{ ZK-454-3 } & $\mathrm{FW}$ & 5.4 & 59.4 & 59.341 & 59.341 & 5.108 & 5.108 & 1200 & 0.060 \\
\hline & & SW & 0.6 & 52.6 & 6.593 & 65.934 & 4.524 & 9.632 & 930 & 0.060 \\
\hline & & $5 \mathrm{~W} / 10$ & 0.3 & 52.6 & 3.297 & 69.231 & 4.524 & 14.156 & 851 & 0.056 \\
\hline & & $\mathrm{SW} / 50$ & 0.2 & 52.3 & 2.198 & 71.429 & 4.498 & 18.654 & 818 & 0.057 \\
\hline & & $\mathrm{SW} 6 \times \mathrm{SO}_{4}{ }^{2-}$ & 0.1 & 52.45 & 1.099 & 72.527 & 4.511 & 23.164 & 811 & 0.070 \\
\hline \multirow[t]{3}{*}{3} & \multirow[t]{3}{*}{ ZK-454-4 } & $5 \mathrm{~W} / 10$ & 7.2 & 64 & 72.000 & 72.000 & 5.227 & 5.227 & 1105 & 0.045 \\
\hline & & $\mathrm{SW} / 50$ & 0.3 & 52.5 & 3.000 & 75.000 & 4.288 & 9.515 & 811 & 0.059 \\
\hline & & $\mathrm{SW} 6 \times \mathrm{SO}_{4}^{2-}$ & 0.1 & 52.5 & 1.000 & 76.000 & 4.288 & 13.803 & 788 & 0.074 \\
\hline \multirow[t]{2}{*}{4} & \multirow[t]{2}{*}{ ZK-454-5 } & $\mathrm{SW} / 50$ & 8.1 & 63.1 & 71.681 & 71.681 & 4.632 & 4.632 & 381 & 0.123 \\
\hline & & $\mathrm{SW} 6 \times \mathrm{SO}_{4}^{2-}$ & 0.2 & 52.7 & 1.770 & 73.451 & 3.869 & 8.501 & 320 & 0.180 \\
\hline \multirow[t]{2}{*}{5} & \multirow[t]{2}{*}{ ZK-454-13 } & $\mathrm{SW} 6 \times \mathrm{SO}_{4}^{2-}$ & 7.4 & 63 & 64.348 & 64.348 & 4.016 & 4.016 & 513 & 0.100 \\
\hline & & SW/50 & 0.45 & 52.6 & 3.913 & 68.261 & 3.353 & 7.369 & 415 & 0.101 \\
\hline
\end{tabular}

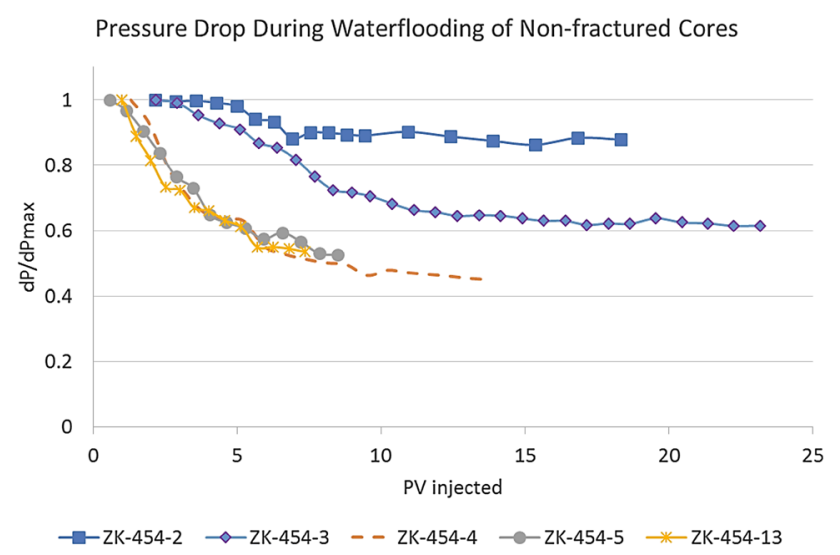

Fig. 6 Flow resistance index versus pore volume injected of five sequential scenarios of brines flooding in non-fractured systems

of improved oil displacement by low-salinity brines. The improved effectiveness of low-salinity brines in displacing oil may be attributed to mineral dissolution and thus improved alteration of wettability to the more favorable water-wet status.

Also shown in Table 8 is that the highest recovery factor was achieved in sequential number 3. Results of end-point effective permeability at $S_{o r}$ at the end of each stage of a certain sequential flooding scenario indicate a shift of $K_{\text {weff }}$ to higher values. This shift supports the wettability alteration as being the dominant mechanism which is responsible for the improved oil recovery. Spiking of $\mathrm{SW}$ with $\mathrm{SO}_{4}{ }^{-2}$ improved the oil recovery by $3 \%$.
Figure 6 presents a proposed flow resistance index as a function of pore volumes of injected brine. During any scenario of sequential brine flooding, the flow resistance index is defined as the ratio of pressure drop across the core sample to the maximum pressure drop across the core. These results show that sequential scenario number 3 is one of three sequential flooding scenarios which exhibited a significant reduction of the flow resistance index. This observation confirms our previous postulation regarding alteration of wettability as being the dominant mechanism that contributes to improved oil recovery.

\section{Sequential low-salinity waterflooding in fractured cores}

Many operators believe that development of tight oil reservoirs can only be achieved by hydraulic fracturing. In this section, the performance of sequential brine flooding in core samples with synthetic fractures is evaluated and compared with that of the non-fractured systems. A Summary of the results of sequential coreflooding by various brines in four fractured cores under simulated reservoir conditions of pressure and temperature are presented in Table 9. By comparing the results presented in Tables 8 and 9 and the results shown in Fig. 6, and for similar sequential scenarios of brine flooding, it is clear that there is a significant increase of oil recovery in fractured cores. For example, a 5\% additional oil recovery could be obtained when using the SW/10 brine in fractured system over the non-fractured system. The optimum sequential scenario of brine flooding in fractured cores 
Table 9 Summary of results of sequential brine flooding scenarios in synthetically fractured cores

\begin{tabular}{|c|c|c|c|c|c|c|c|c|c|c|}
\hline No. & Core ID & Injected Brines & $\begin{array}{l}\text { Voil } \\
\text { produced } \\
\text { (cc) }\end{array}$ & $\begin{array}{l}\text { Vwater } \\
\text { injected } \\
\text { (cc) }\end{array}$ & $\begin{array}{l}\text { Incre- } \\
\text { mental } \\
\operatorname{RF}(\%)\end{array}$ & $\mathrm{RF}(\%)$ & $\begin{array}{l}\text { Incremental } \\
\text { PV injected }\end{array}$ & PV injected & AP at Sor (psi) & $\begin{array}{l}\mathrm{Kw}_{\text {eff }} \text { at Sor } \\
\text { estimated (mil- } \\
\text { lidarcy) }\end{array}$ \\
\hline \multirow[t]{5}{*}{1} & \multirow[t]{5}{*}{ ZK-454-6F } & FW & 4.6 & 60.9 & 65.714 & 65.714 & 6.711 & 6.711 & 413 & 0.135 \\
\hline & & SW & 0.45 & 51.85 & 6.429 & 72.143 & 5.713 & 12.424 & 320 & 0.135 \\
\hline & & SW/10 & 0.25 & 52.25 & 3.571 & 75.714 & 5.757 & 18.181 & 280 & 0.133 \\
\hline & & $\mathrm{SW} / 50$ & 0.15 & 51.35 & 2.143 & 77.857 & 5.658 & 23.840 & 260 & 0.139 \\
\hline & & $\mathrm{SW} 6 \times \mathrm{SO}_{4}{ }^{2-}$ & 0.1 & 52.1 & 1.429 & 79.286 & 5.741 & 29.580 & 285 & 0.155 \\
\hline \multirow[t]{3}{*}{2} & \multirow[t]{3}{*}{ ZK-454-11F } & $\mathrm{SW} / 10$ & 5.55 & 60.75 & 77.083 & 77.083 & 6.144 & 6.144 & 289 & 0.111 \\
\hline & & $\mathrm{SW} / 50$ & 0.25 & 51.75 & 3.472 & 80.556 & 5.234 & 11.378 & 197 & 0.158 \\
\hline & & $\mathrm{SW} 6 \times \mathrm{SO}_{4}{ }^{2-}$ & 0.15 & 52.05 & 2.083 & 82.639 & 5.264 & 16.642 & 219 & 0.174 \\
\hline \multirow[t]{4}{*}{3} & \multirow[t]{4}{*}{ ZK-454-20F } & SW & 5.3 & 58.6 & 71.622 & 71.622 & 6.479 & 6.479 & 313 & 0.120 \\
\hline & & SW/10 & 0.3 & 52.6 & 4.054 & 75.676 & 5.815 & 12.294 & 308 & 0.105 \\
\hline & & SW/50 & 0.1 & 52 & 1.351 & 77.027 & 5.749 & 18.043 & 296 & 0.106 \\
\hline & & $\mathrm{SW} 6 \times \mathrm{SO}_{4}{ }^{2-}$ & 0.1 & 51.1 & 1.351 & 78.378 & 5.650 & 23.693 & 293 & 0.131 \\
\hline \multirow[t]{2}{*}{4} & \multirow[t]{2}{*}{ ZK-454-27F } & $\mathrm{SW} 6 \times \mathrm{SO}_{4}{ }^{2-}$ & 6.75 & 56.85 & 67.500 & 67.500 & 4.579 & 4.579 & 299 & 0.156 \\
\hline & & $\mathrm{SW} / 50$ & 0.4 & 52.7 & 4.000 & 71.500 & 4.244 & 8.823 & 228 & 0.167 \\
\hline
\end{tabular}

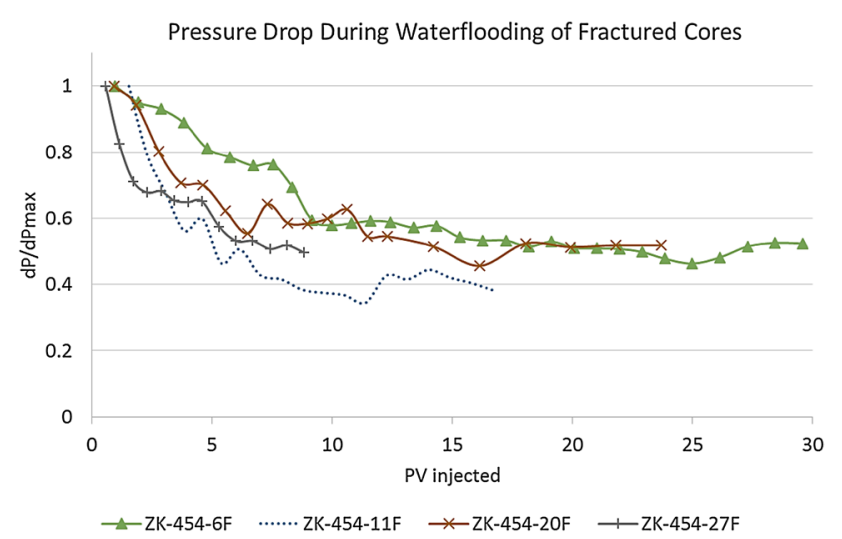

Fig. 7 Flow resistance index versus pore volumes of injected brines in fractured systems

is number 2 for core $\mathrm{ZK}-454-11 \mathrm{~F}(\mathrm{SW} / 10 \rightarrow \mathrm{SW} / 50 \rightarrow \mathrm{SW}$ $6 \times \mathrm{SO}_{4}{ }^{-2}$ ) which resulted in oil recovery of $82.639 \%$ of the OOIP. Fractured and non-fractured systems, however, share similar optimum brine flooding of SW/10.

As depicted in Fig. 7, a plot of the flow resistance index versus pore volumes of injected brine exhibits similar trends as for the non-fractured systems. Similar trends of end-point effective permeabilities are also observed for both systems. Therefore, similar conclusions may be drawn regarding the mechanism responsible for improved oil recovery, i.e., mineral dissolution that leads to a more favorable wetting characteristics.

The results of all scenarios of sequential brine flooding tests in fractured and non-fractured core samples are illustrated in Fig. 8. It can be stated that using the SW/10 brine in the secondary recovery mode in fractured cores is found to yield the highest oil recovery of $82.64 \%$ of the original OOIP.

\section{Monitoring brines' properties}

Brine water properties including salinity, resistivity, conductivity, $\mathrm{pH}$, and TDS before and after each stage of each sequential brine flooding scenario were measured. The results of such measurements of one scenario of sequential brine flooding are presented in Table 10. Total TDS of the effluent water was calculated using a reliable TDS converter software developed by Chemia-soft which converts brine conductivity to TDS. These results show that the maximum mineral dissolution is observed during SW/10 brine flooding stage as the TDS was increased by $295 \%$. This observation also confirms our previously mentioned postulation of mineral dissolution which could have changed rock surface properties to the favorable wettability characteristics. These findings are in line with those obtained by Zahid et.al. (2012).

As indicated in Table 10, when the salinity of the effluent water increases, the resistivity will decrease and so will the conductivity. Measurements of the $\mathrm{pH}$ values, in fact, show that there is a correlation between the above properties. No significant change in the $\mathrm{pH}$ value was observed during the SW/10 stage. Other stages of sequential flooding such as flooding with SW/50 displayed an increase in $\mathrm{pH}$ value. Consequently, no clear conclusion regarding the recovery mechanism can be drawn based on these results. 
Fig. 8 Results of sequential brine flooding tests of all scenarios
Table 10 Results of measurements of supportive brine water properties of one scenario of sequential brine flooding

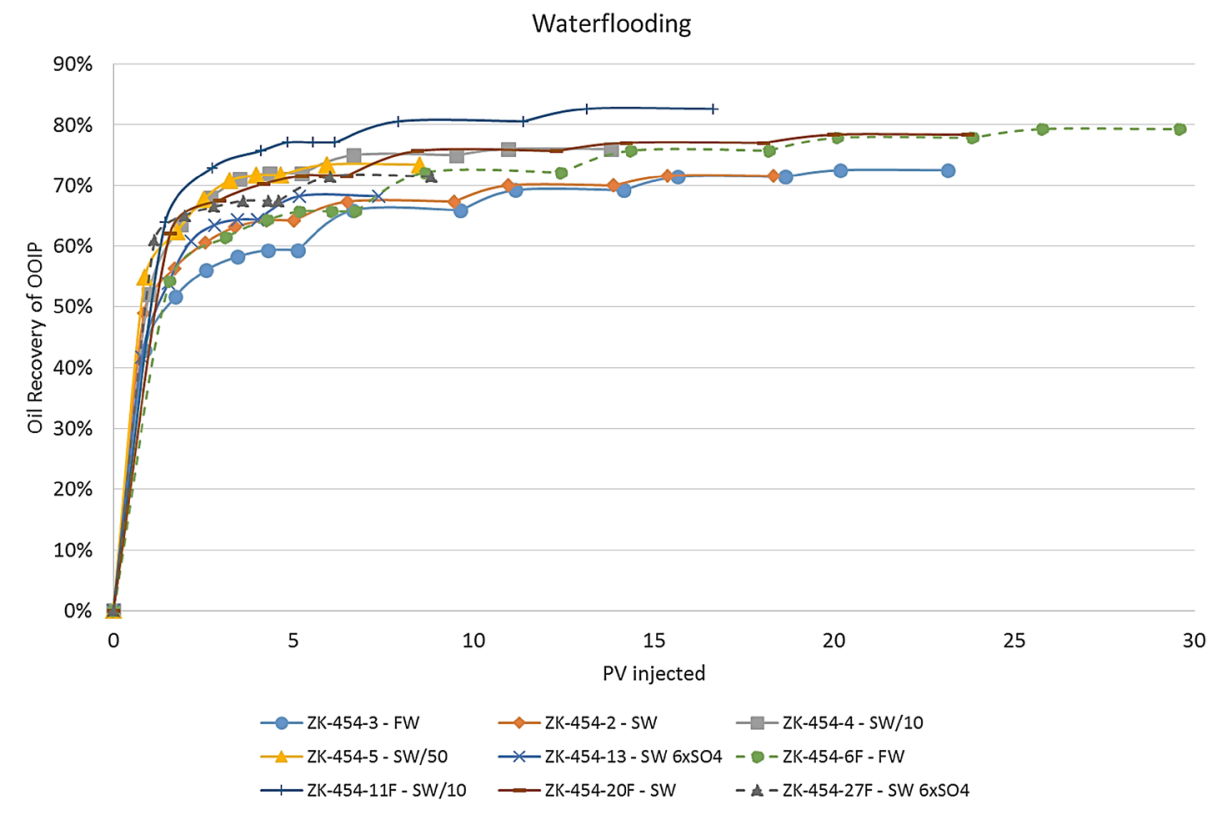

\begin{tabular}{|c|c|c|c|c|c|c|c|c|c|c|}
\hline \multirow[t]{2}{*}{ Injected Water } & \multicolumn{2}{|c|}{ Salinity (ppm) } & \multicolumn{2}{|c|}{$\begin{array}{l}\text { Resistivity } \\
\text { (ohm*meter) }\end{array}$} & \multicolumn{2}{|c|}{$\begin{array}{l}\text { Conductivity } \\
(\mathrm{mS} / \mathrm{cm})\end{array}$} & \multicolumn{2}{|l|}{$\mathrm{pH}$} & \multicolumn{2}{|c|}{ TDS (mg/L) } \\
\hline & Before & After & Before & After & Before & After & Before & After & Before & After \\
\hline FW & 157,662 & 117,314 & 0.068 & 0.071 & 197.2 & 189.5 & 7.12 & 6.98 & 157,482 & 123,322 \\
\hline SW & 62,522 & 69,259 & 0.136 & 0.104 & 89.9 & 125.3 & 7.22 & 6.89 & 62,451 & 83,779 \\
\hline SW/10 & 6252 & 20,584 & 1 & 0.291 & 11.63 & 40 & 7.17 & 7.18 & 6245 & 24,673 \\
\hline $\mathrm{SW} / 50$ & 1250 & 4496 & 3.53 & 1.21 & 3.13 & 9.47 & 7 & 7.33 & 1249 & 5446 \\
\hline $\mathrm{SW} 6 \times \mathrm{SO}_{4}^{2-}$ & 72,927 & 56,565 & 0.133 & 0.174 & 90 & 71 & 7.35 & 7.23 & 72,844 & 59,194 \\
\hline
\end{tabular}

\section{Conclusions}

Based on the results of this work the following conclusions can be drawn:

1. Sequential flooding scenarios which begin with the injection of sea water diluted ten times (SW/10) have been found to yield highest oil recoveries. In non-fractured core samples, the highest oil recovery was $76 \%$ of OOIP and was achieved with the sequential flooding scenario which begins with SW/10 followed by SW/50 followed by SW $6 \times \mathrm{SO}_{4}{ }^{-2}$ (Table 8). In fractured core samples, the highest reported oil recovery was $82.64 \%$ of OOIP and was achieved with the sequential flooding scenario which begins with SW/10 followed by SW/50 followed by SW $6 \times \mathrm{SO}_{4}{ }^{-2}$ (Table 9).

2. Adding divalent sulfate ion to low-salinity water would increase the overall cost of the oil recovery process and may not necessarily improve the effectiveness of oil displacement by the low-salinity water.
3. It is postulated that mineral dissolution and favorable shift of end-point effective permeability could lead to a more favorable wettability condition. This mechanism of oil displacement by sequential brine flooding has been confirmed by monitoring "flow resistance index" proposed in this work and measuring key properties of brine water before and after sequential flooding.

Acknowledgements Financial support and samples of this work are gratefully acknowledged from the Abu Dhabi Company for Onshore Petroleum Operations Ltd. (ADCO), Contract No. 21R011-The Petroleum Institute. Also authors would like to thank UAE U research sector for their support.

Open Access This article is distributed under the terms of the Creative Commons Attribution 4.0 International License (http://creativeco mmons.org/licenses/by/4.0/), which permits unrestricted use, distribution, and reproduction in any medium, provided you give appropriate credit to the original author(s) and the source, provide a link to the Creative Commons license, and indicate if changes were made. 


\section{References}

Alameri W, Teklu TW, Graves RM, Kazemi H, AlSumaiti AM (2015) Experimental and numerical modeling of low-salinity waterflood in a low-permeability carbonate reservoir. Paper SPE-174001-MS. SPE Western regional Meeting, California

Al-Attar HH, Mahmoud MY, Zekri AY, AImehaideb R, Ghannam M (2013) Low-salinity flooding in a selected carbonate reservoir: experimental approach. J Pet Explor Prod Technol 3(2):139-149. https://doi.org/10.1007/s13202-013-0052-3

Al-Harrasi A, Al-maamari RS, Masalmeh SK (2012) Laboratory investigation of low-salinity waterflooding for carbonate reservoirs. Soc Pet Eng. https://doi.org/10.2118/161468-MS

Al-Quraishi AA, Al Hussinan SN, Al Yami HQ (2015). Efficiency and recovery mechanisms of low-salinity waterflooding in sandstone and carbonate reservoir. In: Proceedings of the Offshore Mediterranean Conference and Exhibition, OMC-2015- 223, Ravenna, Italy

Austad T, RezaeiDoust A, Puntervold T (2010) Chemical mechanism of low-salinity water flooding in sandstone reservoirs. Paper SPE129767 presented at the SPE Improved Oil Recovery Symposium.Tulsa, OK, 24-28 Apr 2010

Bagci S, Kok MV, Turksoy U (2001) Effect of brine composition on oil recovery by waterflooding. Pet Sci Technol. 19(3-4):359-372. https://doi.org/10.1081/LFT-100000769

Ban J, Arellano JL, Alawami A, Aguilera RF, Tallett M (2016) World Oil Outlook. Organization of the Petroleum Exporting Countries
Benny A, Harahap (2017) Laboratory investigation of oil recovery efficiency achieved by low-salinity waterflooding in low-permeability fractured and non-fractured chalky limestone cores, M.Sc. Thesis submitted to the College Of Engineering, Chemical \& Petroleum Engineering Department, UAE University, Dec 2017

El-Dessouky HT, Ettouney HM (2002) Fundamentals of sea water desalination. Elsevier, Amsterdam

Sheng JJ (2014) Critical review of low-salinity water flooding. J Pet Sci Eng 120:216-224. https://doi.org/10.1016/j.petrol.2014.05.026

Yi Z, Sarma HK (2012) Improving waterflood recovery efficiency in carbonate reservoirs through salinity variations and ionic exchanges: a promising low-cost 'Smart-Waterflood' approach. In: Proceedings of the Abu Dhabi International Petroleum Conference and Exhibition, SPE-161631-MS, Abu Dhabi, UAE

Zahid A, Shapiro AA, Skauge A (2012) Experimental studies of lowsalinity waterflooding carbonate: a new promising approach. In: Proceedings of the SPE EOR Conference at Oil and Gas West Asia, SPE-155625-MS, Muscat, Oman

Zekri AY, Nasr MS, Al-Arabai ZI (2011) Effect of losal on wettability and oil recovery of carbonate and sandstone format ion. Int Pet Technol Conf. https://doi.org/10.2523/IPTC-14131-MS

Publisher's Note Springer Nature remains neutral with regard to jurisdictional claims in published maps and institutional affiliations 